\title{
Neuroinflammation in HIV-Related Neuropathic Pain
}

\author{
Huan-Jun Lu', Yuan-Yuan Fu, ${ }^{1,2}$, Qian-Qi Wei ${ }^{3 *}$ and Zhi-Jun Zhang ${ }^{1,2 *}$ \\ ${ }^{1}$ Institute of Pain Medicine and Special Environmental Medicine, Nantong University, Jiangsu, China, ${ }^{2}$ Department of Human \\ Anatomy, School of Medicine, Nantong University, Nantong, China, ${ }^{3}$ Department of Infectious Diseases, General Hospital of Tibet \\ Military Command, Xizang, China
}

\section{OPEN ACCESS}

Edited by: Francisco Lopez-Munoz, Camilo José Cela University, Spain

Reviewed by:

Shao-Jun Tang,

University of Texas Medical Branch at Galveston, United States

Ting $X u$,

Zhongshan School of Medicine, Sun Yat-sen University, China

Mohammad Zakir Hossain, Matsumoto Dental University, Japan

${ }^{*}$ Correspondence: Qian-Qi Wei infection0522@gmail.com

Zhi-Jun Zhang zhzhi@ntu.edu.cn

Specialty section: This article was submitted to Neuropharmacology, a section of the journal Frontiers in Pharmacology

Received: 15 January 2021 Accepted: 31 March 2021

Published: 20 April 2021

Citation:

Lu H-J, Fu Y-Y, Wei Q-Q and Zhang Z-J (2021) Neuroinflammation in HIV-Related Neuropathic Pain.

Front. Pharmacol. 12:653852. doi: 10.3389/fphar.2021.653852
In the management of human immunodeficiency virus (HIV) infection around the world, chronic complications are becoming a new problem along with the prolonged life expectancy. Chronic pain is widespread in HIV infected patients and even affects those with a low viral load undergoing long-term treatment with antiviral drugs, negatively influencing the adherence to disease management and quality of life. A large proportion of chronic pain is neuropathic pain, which defined as chronic pain caused by nervous system lesions or diseases, presenting a series of nervous system symptoms including both positive and negative signs. Injury caused by HIV protein, central and peripheral sensitization, and side effects of antiretroviral therapy lead to neuroinflammation, which is regarded as a maladaptive mechanism originally serving to promote regeneration and healing, constituting the main mechanism of HIV-related neuropathic pain. Gp120, as HIV envelope protein, has been found to be the major toxin that induces neuropathic pain. Particularly, the microglia, releasing numerous pro-inflammatory substances (such as TNF $\alpha, I L-1 \beta$, and IL-6), not only sensitize the neurons but also are the center part of the crosstalk bridging the astrocytes and oligodendrocytes together forming the central sensitization during HIV infection, which is not discussed detailly in recent reviews. In the meantime, some NRTIs and Pls exacerbate the neuroinflammation response. In this review, we highlight the importance of clarifying the mechanism of HIV-related neuropathic pain, and discuss about the limitation of the related studies as future research directions.

Keywords: neuroinfalmmation, Chemokine, HIV, Human immunodeficiency virus, microglia, neuropathic pain (NP)

Abbreviations: BBB, blood-brain-barrier; BDNF, brain-derived neurotropic factor; CCAT, cytosine-cytosine-adenosineadenosine-thymidine; CaMKII, Calmodulin-dependent Protein kinase II; cART, combination antiretroviral therapy; CDK9, Cyclin-dependent kinase 9; CCR5, C-C chemokine receptor 5; cNOS, constitutive nitric oxide synthase; CNS, central nervous system; CXCR4, CXC chemokine receptor 4; DRG, dorsal root ganglion; FKN, fractalkine; GM-CSF, granulocyte-macrophage colony-stimulating factor; HIV, human immunodeficiency virus; IL-1 $\beta$, interleukin-1 $\beta$; JNK, c-jun N-terminal kinase; MCP-1, monocyte chemoattractant protein-1; NR1, NMDA receptor subunit 1; NRTIs, Nucleoside analogue reverse transcriptase inhibitors; pCREB, cAMP response element binding protein; PIs, protease inhibitors; PLWH, people living with HIV; PNS, peripheral nervous system; PSD-95, postsynaptic density-95; SDF-1, stromal cell-derived factor-1; Syn I, synapsin I; Tat, transactivator of transcription; TNFR1, TNF receptor 1; Vpr, viral protein R; Wnt5a, wingless-type mammary tumor virus integration site family member $5 \mathrm{~A}$. 


\section{INTRODUCTION}

Combination antiretroviral therapy (cART) has opened a new age in the treatment of HIV, in particular creating a new group of patients known as people living with HIV (PLWH). However, in addition to the immunodeficiency disease caused by HIV infection, various complications influence the mortality and treatment compliance among PLWH. According to the International Association for the Study of Pain (IASP), chronic pain is defined as pain that lasts or recurs for longer than 3 months, which is one of the consistently encountered symptoms in PLWH and is significantly associated with disability in daily activities, unemployment, and reduced quality of life (Ellis et al., 2010; Treede et al., 2019). Chronic neuropathic pain is chronic pain caused by nervous system lesions or diseases. Certain types of chronic pain are commonly identified as neuropathic pain, including spontaneous pain (continuous or episodic), hyperalgesia (exaggerated responses to normally painful), and mechanical allodynia (a painful response to a normally nonpainful stimulus) (Ji et al., 2003; Tsuda, 2018; Scholz et al., 2019). On clinical examination, the symptoms may present as positive signs (gain of somatosensory function), such as "pins and needles" sensation, painful ongoing sensation etc., or present as negative signs (loss of somatosensory function), such as distal sensory loss, reduced tendon reflexes, reduced temperature perception etc., but it is required that a history of nervous system injury or disease and a neuroanatomically plausible distribution of the pain to make the diagnosis (Tagliati et al., 1999; Gierthmuhlen and Baron, 2016; Scholz et al., 2019).

Neuroinflammation is a maladaptive mechanism responding to tissue injury in neuron system with the recruitment of immune cell and mediator releasing to promote regeneration and healing (Ellis and Bennett, 2013; Sommer et al., 2018). The combination and release of HIV-related glycoproteins (such as gp120) damage neurons, inducing neuroinflammation by a series of downstream alterations, increasing responses between neurons and glial cells and resulting in central sensitization and/or peripheral sensitization. These responses macroscopically present as chronic neuropathic pain in patients or rat models. Nucleoside analogue reverse transcriptase inhibitors (NRTIs) and protease inhibitors (PIs) that are used in the treatment of HIV also have neurotoxic effects, thereby exacerbating the neuropathic pain symptoms in PLWH as well. Recent reviews make a great introduction to the mechanism in chronic pain and clinical care for PLWH with chronic pain indicating that the inflammation response might play an important role in development of pain (Addis et al., 2020; Madden et al., 2020). In this review, we focus more on neuropathic pain and elucidate the mechanism of neuroinflammation in HIV-related neuropathic pain, for helping stimulate future researches about new targets to relief this torturous problem in PLWH.

\section{Epidemiology}

The prevalence of chronic pain ranges from 25 to $90 \%$ (Newshan et al., 2002; Lee et al., 2009; Nair et al., 2009; Silverberg et al., 2009; Aouizerat et al., 2010; Cervia et al., 2010; Harding et al., 2010;
Miaskowski et al., 2011; Merlin et al., 2012; Merlin et al., 2013; Parker et al., 2014; Lawson et al., 2015; Merlin et al., 2018), and some researches have highlighted the prevalence of neuropathic pain. $32 \%$ to more than a half of the participants reported neuropathic pain (Simpson et al., 2006; Nair et al., 2009; Robinson-Papp et al., 2009; Ellis et al., 2010). This variability can be partly attributed to different research methods, participants and definition of the origins of pain. Nonneuropathic pain, such as nociceptive pain, can be caused by tissue injury resulting from inflammation (e.g., autoimmune responses), infection (e.g., bacteria, other viruses, tuberculosis), or neoplasia (e.g., lymphoma or sarcoma) (Bruce et al., 2017). Considering the limitation of the questionnaire or self-report data, it is difficult to distinguish whether chronic pain is due to pathogen, neuropathy, or just cART induced. Additionally, patients with $\mathrm{HIV}$-associated neuropathy are more than twice as likely to have other chronic pain disorders (Navis et al., 2018). Regardless of the types of pain, in fact more than $50 \%$ of PLWH have moderate to severe pain that affects daily life (Miaskowski et al., 2011; Merlin et al., 2012).

Certain demographic variables are associated with pain intensity, including female sex, non-Caucasian race, lower education level, and a history of drug use (Breitbart et al., 1996; Tsao et al., 2010; Miaskowski et al., 2011) (Table 1). Jiao et al. analyzed 638 patients and showed that 38\% were affected by musculoskeletal pain, whereas $11 \%$ suffered from neuropathic pain including peripheral neuropathy (Jiao et al., 2016).

\section{The Mechanism Leading to HIV-Related Neuropathic Pain}

Pathological pain in HIV patients is frequently associated with peripheral sensory neuropathy, which is a form of the so-called "dying-back" degeneration of sensory neurons (Hao, 2013). As the reasons for non-neuropathic chronic pain in diversified sites remain uncertain (e.g., musculoskeletal), the neuropathic pain related to HIV infection has been shown to be caused by neurotoxic effect of virus and the drugs applicated to treat HIV (Madden et al., 2020). Tough there is no existence of productive HIV infection in neurons, viral proteins do interact with neurons, glial cells, and immune cells both in central and peripheral nervous systems to inducing the development of neuroinflammation, macroscopic hyperalgesia and allodynia, a process that could be exacerbated by antiretroviral drugs.

\section{Viral Protein gp120 Is the Major Toxin Inducing the Neuropathic Pain}

The HIV envelope glycoprotein gp120, together with gp41, undergoes receptor-driven conformational changes upon engaging the $\mathrm{CD} 4$ receptor and $\mathrm{C}-\mathrm{C}$ chemokine receptor 5 (CCR5)/CXC chemokine receptor 4 (CXCR4) co-receptor binding for fusion of viral and host cell membranes (Acharya et al., 2015). As infection seldom occurs in neuronal cells, gp120 triggers hyperalgesia by directly activating the CXCR4 and/or CCR5 chemokine receptors in dorsal root ganglion (DRG) 
TABLE 1 | Prevalence of pain, assessment method, and related factors in different chronic pain studies.

\begin{tabular}{|c|c|c|c|c|c|}
\hline Articles & $\begin{array}{l}\text { Prevalence of } \\
\text { pain }\end{array}$ & $\begin{array}{l}\text { Method of } \\
\text { assessment }\end{array}$ & Influence factors & cART usage & Drug regimens \\
\hline $\begin{array}{l}\text { Merlin et al.; Merlin } \\
\text { et al. (2018) }\end{array}$ & $\begin{array}{l}25 \% \text { of } 2,334 \\
\text { participants }\end{array}$ & $\begin{array}{l}\text { Questionnaire (BCPQ Merlin } \\
\text { et al.(2014) and PEG Krebs et al. } \\
\text { (2009)) }\end{array}$ & Long-term opioid therapy & $\begin{array}{l}\text { All participants } \\
\text { received HIV care } \\
\text { services }\end{array}$ & No detailed description \\
\hline $\begin{array}{l}\text { Lawson et al. Lawson } \\
\text { et al. (2015) }\end{array}$ & $62.8 \%$ of 859 & $\begin{array}{l}\text { Questionnaire (Urwin Urwin et al. } \\
\text { (1998)) }\end{array}$ & $\begin{array}{l}\text { Age, diagnosis time, } \mathrm{Pl} \\
\text { regimen }\end{array}$ & $76.5 \%$ on $\mathrm{cART}$ & pl/NNRTI/NRTI based \\
\hline $\begin{array}{l}\text { Miaskowski et al. } \\
\text { Miaskowski et al. } \\
\text { (2011) }\end{array}$ & 270 of 296 & $\begin{array}{l}\text { Questionnaire (BPI Cleeland and } \\
\text { Ryan, (1994) and PQAS Jensen et al. } \\
\text { (2006)) }\end{array}$ & Gender, education & $74.4 \%$ on cART & No detailed description \\
\hline $\begin{array}{l}\text { Cervia et al. Cervia } \\
\text { et al. (2010) }\end{array}$ & $39 \%$ of 41 & Self-reported pain scale data & CART & $26 \%$ on cART & $\begin{array}{l}18 \text { different kinds of } \\
\text { regimens }\end{array}$ \\
\hline $\begin{array}{l}\text { Harding et al. Harding } \\
\text { et al. (2010) }\end{array}$ & $53.2 \%$ of 778 & $\begin{array}{l}\text { Questionnaire (MSAS) ( Chang et al. } \\
(2000)\end{array}$ & Education & $\begin{array}{l}67.4 \% \text { on cART } \\
\text { currently }\end{array}$ & No detailed description \\
\hline $\begin{array}{l}\text { Aouizerat et al. } \\
\text { Aouizerat et al. (2010) }\end{array}$ & $55 \%$ of 317 & Questionnaire (MSAS) & $\begin{array}{l}\text { CD4 }{ }^{+} \mathrm{T} \text {-cell count, race, sleep } \\
\text { disturbance }\end{array}$ & $\begin{array}{l}71 \% \text { on cART } \\
\text { currently }\end{array}$ & No detailed description \\
\hline $\begin{array}{l}\text { Nair et al. Nair et al. } \\
(2009)\end{array}$ & $\begin{array}{l}24.5 \% \text { of } 98 \text { out- } \\
\text { patients }\end{array}$ & Questionnaire (BPI) & $\mathrm{CART}$ & Partially usage & No detailed description \\
\hline $\begin{array}{l}\text { Lee et al. Lee et al. } \\
\text { (2009) }\end{array}$ & $55 \%$ of 317 & Questionnaire (MSAS) & $\begin{array}{l}\text { AIDS diagnosis, race, gender, } \\
\text { CART }\end{array}$ & $70 \%$ on cART & $\begin{array}{l}\text { Include NRTI/PI based, or } \\
\text { other combination therapy }\end{array}$ \\
\hline $\begin{array}{l}\text { Silverberg et al. } \\
\text { Silverberg et al. (2009) }\end{array}$ & $\begin{array}{l}41.4 \% \text { of } 1,574 \\
\text { women } \\
43.1 \% \text { of } \\
955 \text { men }\end{array}$ & Self-report data & $\begin{array}{l}\text { Race/ethnicity, age, } \\
\text { depression and AIDS } \\
\text { diagnosis }\end{array}$ & $\begin{array}{l}83.1 \% \text { on } \mathrm{CART} \text { of } \\
\text { women } \\
90.8 \% \text { on } \mathrm{CART} \\
\text { of men }\end{array}$ & $\begin{array}{l}43.1 \% \mathrm{Pl} \text {-containing of } \\
\text { women } \\
50.1 \% \mathrm{Pl} \text {-containing } \\
\text { of men }\end{array}$ \\
\hline $\begin{array}{l}\text { Newshan et al. } \\
\text { Newshan et al. (2002) }\end{array}$ & $46 \%$ of 484 & Clinic symptom checklist & None & $\begin{array}{l}\text { No detailed } \\
\text { description }\end{array}$ & No detailed description \\
\hline $\begin{array}{l}\text { Breitbart et al. } \\
\text { Breitbart et al. (1996) }\end{array}$ & $62 \%$ of 438 & Questionnaire (BPI and MSAS) & $\begin{array}{l}\text { HIV-related conditions, } \\
\text { antiretroviral medications, age, } \\
\text { and race }\end{array}$ & $\begin{array}{l}\text { No detailed } \\
\text { description }\end{array}$ & No detailed description \\
\hline
\end{tabular}

neurons (Oh et al., 2001). There are some reports that other HIV proteins such as Tat (transactivator of transcription) and $\mathrm{Vpr}$ (viral protein $\mathrm{R}$ ) could also induce neuropathic pain, but a more convincing evidence suggests that gp120 is a major contributor to neuropathic pain (Acharjee et al., 2010; Chi et al., 2011; Yuan et al., 2014). Gp120 levels are about 10-fold higher in the spinal cord dorsal horn of pain-positive HIV patients than in that of pain-negative HIV patients. In contrast to gp120, Tat and Vpr, were not significantly elevated in the spinal cord dorsal horn of pain-positive HIV patients compared to pain-negative HIV patients (Yuan et al., 2014). Evidence supports that gp120 plays a direct role in the induction of allodynia. Symptomless HIV-1 infected patients who received an envelope subcomponent vaccine (MNrgp120) by intramuscular injection monthly report pain at the injection site in 1996 (Eron et al., 1996). Intrathecal injection of gp120 exacerbates pain in a mouse model, inducing robust thermal hyperalgesia and mechanical allodynia similar to the pathological phenotypes of pain-positive HIV-1 patients, followed by the expression of tumor necrosis factora (TNFa) in the spinal cord with the activation of microglia and astrocytes (as discussed below) (Milligan et al., 2000; Milligan et al., 2001a; Herzberg and Sagen, 2001; Zheng W. et al., 2011; Yuan et al., 2014). Injection of TNFa induces neuropathic pain in humans (Eron et al., 1996; Wagner and Myers, 1996; Sorkin and Doom, 2000). Yi et al. elucidates the pathway of TNFa/TNF receptor 1 (TNFR1) -mitochondrial superoxide-pCREB triggers $\mathrm{pC} / \mathrm{EBP} \beta$ in HIV gp120-induced neuropathic pain state in rat model (Yi H. et al., 2018). HIV gp120 upregulates phosphorylated cAMP response element binding protein (pCREB) on the cytosinecytosine-adenosine-adenosine-thymidine (CCAT)/enhancer binding protein $\beta$ (a member of the C/EBP family) gene promoter region via TNFR1 in neurons, which is a critical transcriptional regulator of HIV associated with cyclindependent kinase 9 (CDK9) and influences disease progression (Mameli et al., 2007; Yi Z. et al., 2018).

$\mathrm{TNF} \alpha$ also plays a critical role in the wingless-type mammary tumor virus integration site family member $5 \mathrm{~A}$ (Wnt5a)/c-jun $\mathrm{N}$-terminal kinase (JNK) signaling pathway induced by intrathecal injection of gp 120 . Wnt5a is upregulated in the spinal dorsal horn of HIV patients who develop pain and increased by intrathecal injection of HIV gp120 in rat neuropathic pain models. Inhibition of Wnt5a by specific antagonists blocks gp120-induced upregulation of interleukin$1 \beta$ (IL-1 $\beta$ ), IL-6, and TNFa in the spinal cord. The Wnt5a/Ca2+/ Calmodulin-dependent Protein kinase II (CaMKII) pathway is critical for the gp120-induced expression of IL-1 $\beta$, whereas the Wnt5a/JNK pathway is important for TNFa expression. The expression of IL-6 is co-regulated by both pathways ( $\mathrm{Li}$ et al., 2013).

A gp120-Wnt5a-JNK-TNFa molecular axis is explored by the same group, indicating that Wnt5a potentiates the activity of spinal dorsal horn neurons via the JNK-TNFa pathway (Yuan et al., 2015). Similarly, gp120 combines with CXCR4 that increases cytomembrane outward $\mathrm{K}+$ concentration by activating neuronal voltage-gated potassium (Kv) channels. Caspase-3 activation occurs downstream of the transient 
outward $\mathrm{K}^{+}$currents, leading to neuronal injury (Chen et al., 2011). Gp120 triggers intracellular calcium alterations through a CXCR4-dependent mechanism to induce neuronal damage (Catani et al., 2000; Marchionni et al., 2012) (Figure 1).

\section{Central Sensitization and Peripheral Sensitization in HIV-Related Neuropathic Pain}

Triggered by nerve damage, including infection, inflammation or drug toxicity, neuropathic pain is involved in both central sensitization, increased responsiveness of nociceptive neurons in the central nervous system (CNS) to their normal or subthreshold afferent input, and peripheral sensitization, increased responsiveness and reduced threshold of nociceptors to stimulation of their receptive fields in the peripheral nervous system (PNS), inducing the development and maintenance of hyperalgesia and allodynia (Loeser and Treede, 2008; Gao and Ji, 2010). Driven by the release of cytokines, chemokines and neurotransmitters, the activation of non-neuronal cells such as immune cells and glial cells in both CNS (e.g., microglia and astrocytes) and PNS (e.g., macrophages, Schwann cells and satellite cells) plays an important role in neuropathic pain progressing (Huang et al., 2013; Silva et al., 2017; Lee et al., 2018; Liu et al., 2019). Macrophages and microglia express high levels of CD4 and CCR5 and are therefore a prime target for HIV infection, forming a reservoir for reactivation of virus replication. Noteworthy, Intact HIV and its viral protein gp120 could cross the blood-brain-barrier (BBB) via transcytosis or paracellularly, infecting both microglia and astrocytes while in this process, gp120 might be a key in determining whether free virus can cross the BBB (Banks et al., 2001; Hong and Banks, 2015). Noxious factors released from immune-activated, HIV-infected, or gp120stimulated macrophages and microglia may damage peripheral or central pain transmission neurons directly or through an associated cascade in proinflammation pathways, both of which induce hypersensitivity and allodynia related to neuropathic pain. Here we will mainly discuss the mechanism of central and peripheral sensitization induced by HIV infection leading to neuropathic pain.

\section{Central Sensitization}

There are accumulating evidences supporting the critical role of microglia in central sensitization. Microglia are CNS-resident macrophages described as "neuroimmune sentinels" that orchestrate the immune response to invading pathogens, toxins, and cellular debris. Microglial activation exhibits morphological changes from "resting microglia" state and can assume neurotoxic or neuroprotective priming states that determine their responses to danger (Hickman et al., 2013; Qin et al., 2019). Evidences support that microglia act as a key mechanism in the development and maintenance of neuropathic pain, not only in HIV-related neurological injury, but in spinal or sciatic nerve injury and trigeminal neuropathic pain (Ji et al., 2013; Inoue and Tsuda, 2018; Xin, 2019). In response to HIV infection, the rapid activation of microglia may also release neurotoxic factors, including proinflammatory cytokines such as TNFa, IL-1 $\beta$, IL-6 (Milligan et al., 2001a; Schoeniger-Skinner et al., 2007; Liu et al., 2016), chemokines such as monocyte chemoattractant protein-1 (MCP-1), fractalkine (FKN) (Zhao et al., 2017; Ru et al., 2019), excitatory amino acids (Porcheray et al., 2006; Tian et al., 2012), nerve growth factors such as brainderived neurotropic factor (BDNF) (Wang et al., 2017), and reactive oxygen species (Patrizio and Levi, 1994; Holguin et al., 2004). These factors modulate neuroinflammation, which plays an important role in neuropathic pain maintenance compared with systemic inflammation (Ji et al., 2016). In an HIV-1SF162 infected primary human microglial model, El-Hage et al. showed the secretion of IL-8, IL-6, MCP-1, TNFa, and CCL5 is increased in cell culture supernatants (ElHage et al., 2015). P2X7, a subtype of ionotropic P2X receptors, is stimulated by extracellular ATP signals and involved in neuropathic pain. After nerve injury, P2X7 mRNA is predominantly expressed in spinal microglia (Kobayashi et al., 2011). The release/production of IL- $1 \beta$ by microglia may be related to overexpression of the purinergic $\mathrm{P} 2 \mathrm{X} 7$ receptor, which is associated with microglial activation and proliferation (Monif et al., 2016). These cytokines collectively shape the inflammatory response to HIV infection, form a persistent pathological change, and then promote the occurrence of central sensitization in neuropathic pain underlying PLWH.

PLWH suffering from neuropathic pain may have a decrease in the epidermal nerve fiber density as well as neurodegenerative changes (Phillips et al., 2014; Yuan et al., 2014; Mawuntu et al., 2018). Synapse loss often occurs in pain-positive HIV patients. Intrathecal injection of gp120 in the spinal dorsal horn causes a significant decrease of synapse markers such as synapsin I (Syn I), postsynaptic density-95 (PSD-95), and NMDA receptor subunit 1 (NR1). These results suggest that synaptic degeneration is closely connected with HIV-related neuropathic pain (Yuan et al., 2014). Microglia modulate the formation of neuronal synapses and regulate neuronal activity via phagocytosis (Paolicelli et al., 2011; Hong et al., 2016). FKN/CXC3R1 (an FKN receptor predominantly expressed in microglia) signaling-mediated neuron-microglia cross-talking plays a critical role in HIV infection-induced synaptic degeneration ( $\mathrm{Ru}$ et al., 2019). In gp120-treated primary cortical cultures, the expression of the FKN protein in neurons was gradually upregulated over time. Knockout of CX3CR1 restored gp120-induced alteration in synaptic proteins such as PSD-95 and Syn I. This process was triggered by the Wnt/ $\beta$-catenin pathway. Gp120 induces FKN expression and synapse loss via NMDA receptor activation which is often thought to participate in the procedure of presynaptic inhibitory (Lotankar et al., 2017). The NMDAR antagonist APV, Wnt/ $\beta$-catenin signaling suppressor DKK1, or knockout of CX3CR1 alleviates gp120-induced mechanical allodynia in mice, suggesting that the $\mathrm{Wnt} / \beta$-catenin-FKN/CX3CR1 pathway mediates synaptic degeneration associated with HIV neuropathic pain (Ru et al., 2019). The FKN/CX3CR1 pathway is also discussed in recent review of Huang et al. toughly (Huang et al., 2020).

Astrocytes are numerous CNS glial cells, contributing actively to the formation and maintenance of $\mathrm{BBB}$, and form an intricate crosstalk with neurons and immune cells by neurotransmitters, 
inflammatory cytokines or chemokines. (Rothhammer and Quintana, 2015; Ben and Rowitch, 2017; Linnerbauer et al., 2020). Similarly, astrocyte infected by HIV is generally nonproductive but of which reaction is more persistent and occurs in more painful conditions in spinal cord compared with the rapid and dramatic microglial reaction (Gorry et al., 2003; Ji et al., 2018). Astrocytes are activated by gp120 and Tat to produce inflammatory cytokines such as TNFa, IL-1 and IL-6, the chemokine CCL5, and constitutive nitric oxide synthase (cNOS), which is a mediator for the production of pain facilitation (Togashi et al., 1997; Milligan et al., 2001b; Shah et al., 2011a; Shah et al., 2011b; Zheng X. et al., 2011; Sanchis et al., 2020). These chemicals facilitate neuropathic pain via influencing the microenvironment that is essential for neuronal and glial function. The process could be bilateral. For instance, increased TNFa induced MCP-1 expression in spinal cord astrocytes in a JNK-dependent manner, and its production could promote astrocyte glutamate release, both indicating the development of mechanical allodynia (Bezzi et al., 2001; Gao et al., 2010). Reciprocally, astrocytes control the transcriptional programs of microglia and CNS-infiltrating monocytes in a non-cell autonomous manner by regulating granulocyte-macrophage colony-stimulating factor (GM-CSF) (Mayo et al., 2014).

Oligodendrocytes are generally considered as myelinating cells of providing continuous metabolic and trophic support to neurons, believed to be simply victims of the inflammatory reaction (Nave and Trapp, 2008; Zeis and Schaeren-Wiemers, 2008). However, a growing body of evidence suggests that oligodendrocytes take a more active part in immunomodulatory process. It has been reported that oligodendrocytes express cytokines (IL-17A, IL-18, IL-6) (Cannella and Raine, 2004; Tzartos et al., 2008; Ramesh et al., 2012), chemokines (MCP-1, CCL5) (Balabanov et al., 2007; Moyon et al., 2015), complement (C2, C3) (Hosokawa et al., 2003) to participate the communication network between microglia and astrocytes. A study indicates that activation of microglia is followed by astrocyte activation which contributes to oligodendrocyte cell death. This tri-glial dysregulation is dependent on microglia (Gibson et al., 2019). In pain-positive HIV patients, cell markers of the oligodendrocyte lineage, including NG2, PDGFRa, and Olig2, are significantly increased (Shi et al., 2016). These evidences reveal that the activation of the network among microglia, astrocytes and oligodendrocytes is the important neuropathic pain mechanism (Figure 2).

\section{Peripheral Sensitization}

Peripheral nerves are the origin of almost all forms of neuropathic pain (Ramesh et al., 2013). In response to viral infection or peripheral nerve injury, resident macrophages and peripheral glia cells are early activated prior to central ones, exhibiting diverse mechanisms that lead to peripheral sensory neurons sensitization (Ji et al., 2016). As discussed by Addis et al., macrophages traffic to DRG and shape the peripheral neuron inflammatory milieu after HIV infection. By recruiting T helper type 1 (Th1) cells or Th2 cells, macrophages display pro-inflammatory (M1) or proresolution (M2) phenotype (Addis et al., 2020). M1 macrophages are characterized by high expression of pro-inflammatory cytokines such as TNFa, IL-6, IL-1 $\beta$, which induce local neuro-inflammation, leading to the establishment of neuropathic state. Reversely, M2 macrophages produce antiinflammatory cytokine IL-10. The enhancement of IL-10 expression or inhibition of M1 macrophages could attenuate or abolish the neuropathic pain state (Kiguchi et al., 2017; Fonseca et al., 2019; Iwasa et al., 2019). Schwann cells are important glial cells in the peripheral nervous system, which act as insulators of axons. Not only Schwann cells provide metabolic and trophic support for peripheral nerve, but also modulate response to nerve injury (Kim et al., 2018; Sasaki et al., 2018). Though previous works about gp120 interacts with Schwann cells inducing subsequently release of chemokines, resulting in apoptosis of DRG via CCR5 (Keswani et al., 2003; Melli et al., 2006). Recent studies have aroused interests in the function of Schwann cells in HIV-related neuropathic pain from a new perspective. After T-cell line tropic X4 strain gp120 application (infects T-cell lines via CXCR4 but not macrophages), circulating macrophage infiltration into the peripheral nerves induces neuropathic pain. This phenomenon could be caused by the expression of CXCL1, a chemoattractant of macrophages and neutrophils, which is derived from gp120treated cultured Schwann cells but not neurons (Ntogwa et al., 2020). Furthermore, gp120 increases lysosomal exocytosis and enhances release of ATP in primary human Schwann cells by the activation of P2X4 cationic channels. As a consequence, gp120induced lysosomal exocytosis of ATP in Schwann cells elevated intracellular $\mathrm{Ca} 2+$ in DRG neurons, leading to HIV-related neuropathic pain (Datta et al., 2019). Satellite glial cells (SGCs) surround the bodies of DRG neurons and form close shells via gap junctions (Hanani, 2005; Costa and Moreira, 2015). SGCs contribute to neuropathic pain in a way that produce cytokines like IL-1 $\beta$, matrix metalloprotease-2 (MMP-2) (Kawasaki et al., 2008) and modulate the expression of ionotropic $\mathrm{P} 2 \mathrm{X}$ receptors and metabotropic $\mathrm{P} 2 \mathrm{Y}$ receptors like P2X4, P2X7, P2Y12 (Chen et al., 2008; Yi H. et al., 2018; Zhao et al., 2019).

\section{Antiretroviral Drugs Lead to Neuropathic Pain}

The development and increased availability of HAART have dramatically reduced HIV-related morbidity and mortality, restricting HIV as a chronic, inflammatory disease. The prolonged use of cART is associated with the development of neurological disorders despite decreased HIV loads (Brew et al., 2009; Madden et al., 2020). One common neurological disorder induced by side-effect of cART is neuropathic pain.

Certain NRTIs including stavudine (d4T), zidovudine (AZT), didanosine (ddI), and zalcitabine $(\mathrm{ddC})$ are neurotoxic and pivotal for inducing neuropathic pain (Manji, 2000; Yuan et al., 2018). D4T and ddC are notorious among these NRTI drugs and their toxicity has been studied both in vitro and in vivo. $\mathrm{D} 4 \mathrm{~T}$ is widely used as the first-line regimen in low-income countries with limited resources (Loubiere et al., 2010; Asgedom et al., 2020). D4T-based ART 


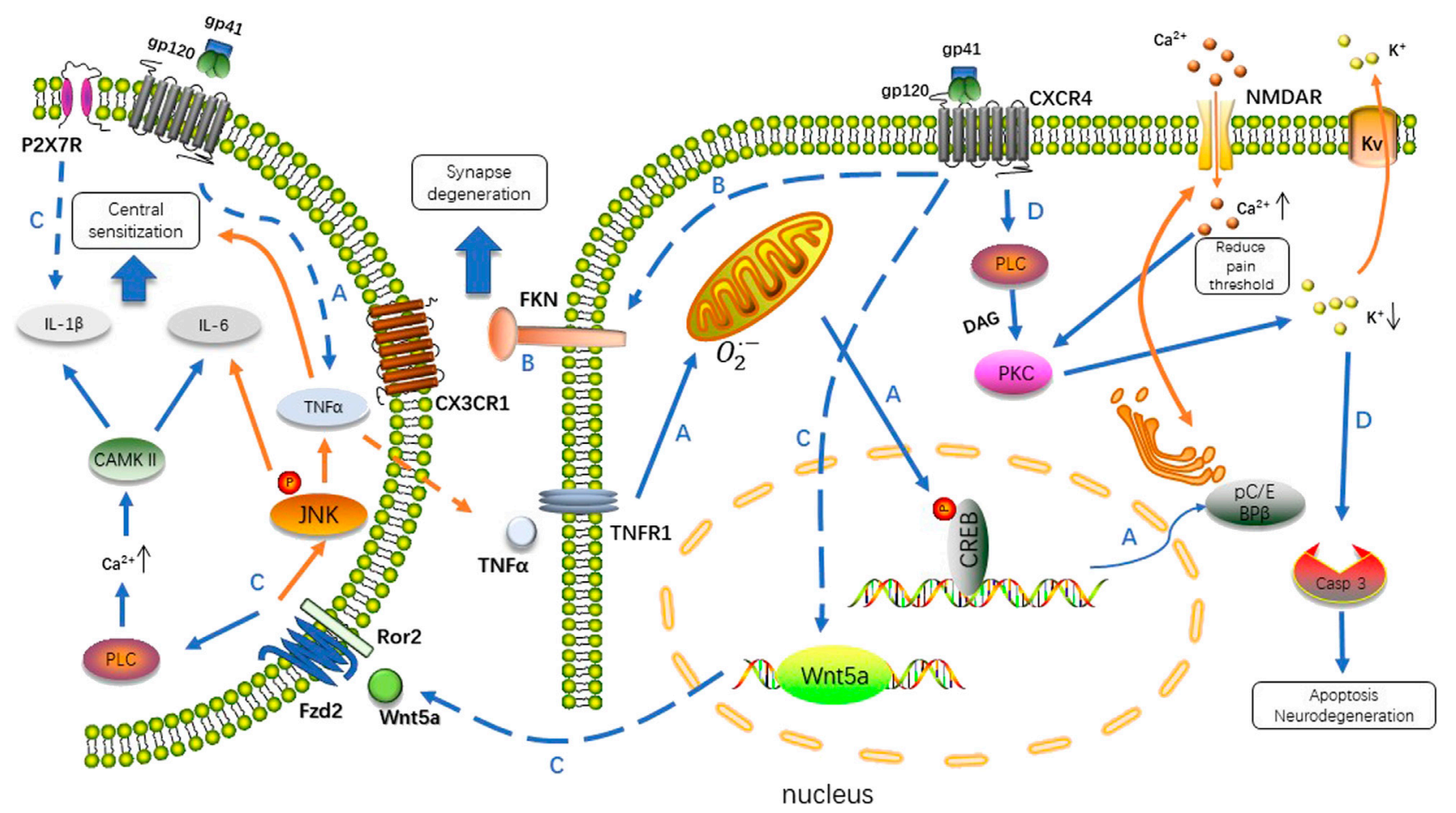

Microglia

Neuron

FIGURE 1 | Gp120 binds to the CXCR4 receptor, and then triggers a series of downstream cellular signaling events involving TNF $\alpha / C R E B / N M D A R$, Wnt/ $\beta$-catenin/ FKN, Wnt5a/JNK/CAMKII and PLC/PKC/caspase 3 signal pathway. The interaction between neurons and microglia in response to infection induces neuropathic pain via different mechanisms. A. Stimulated by gp120, microglia up-regulate TNFa in a way of paracrine, TNF $\alpha / T N F R 1$ signal results in the accumulation of reactive oxygen species in mitochondria, which induced the phosphorylation of CREB triggering the pC/EBP (Zhang et al., 2004). C/EBP promotes recycling of NMDAR regulating the concentration of Ca2+ intracellularly (Wang et al., 2013; Hansen et al., 2018). B. FKN specifically expressed in neurons is upregulated by gp120, which activates microglia through CX3CR1. C. Transcription of Wnt5a is increased after gp120 application, stimulate the production of inflammatory cytokines in a paracrine fashion. Wnt5a/JNK is critical for TNF $\alpha$ expression, whereas Wnt5a/CaMKII is necessary for IL- $1 \beta$ and P2X7R is another factor predominant in driving IL-1 $\beta$ release. The expression of IL-6 is co-regulated by both pathways. D. Exposure of neurons to gp120 produces transient outward K+ currents in a PKC-dependent manner. The alteration of intracellular K+ homeostasis leads to neuronal apoptosis by activation of caspase-3. PLC, phospholipase C; DAG, diacylglycerol; PKC, protein kinase C; Casp 3, caspase 3; Fzd2, Frizzled family receptor 2; Ror2, receptor tyrosine kinase-like orphan receptor 2.

increases the risk of peripheral neuropathy, hyperlactatemia, and other diseases (Menezes et al., 2011). Intraperitoneal injection of $\mathrm{d} 4 \mathrm{~T}$ or $\mathrm{ddC}$ in rat induced mechanical allodynia and cold allodynia (Wallace et al., 2007; Zheng W. et al., 2011; Sanna et al., 2016). Recent study reveals that the expression of 135 genes in mice given injection of $\mathrm{ddC}$ has significant changes mainly enriched in regulation of transcription, multicellular organism development, and cell differentiation via transcriptome sequencing ( $\mathrm{Wu}$ et al., 2021). Exposure to ddC upregulates the pro-nociceptive chemokine MCP-1, stromal cellderived factor-1 (SDF-1), and TNFa in DRG (Bhangoo et al., 2007; Wallace et al., 2007; Zheng X. et al., 2011). AZT/ lamivudine/d4T administration in mice increased TNFa, IL-1 $\beta$ and IL-6 in various CNS regions via a Wnt5a-dependent mechanism (Wu et al., 2017). A direct evidence reported by Yuan et al. suggests that ddC induces neuroinflammation in the spinal cord, with the up-regulation of TNFa and IL-1 $\beta$. It activates astrocytes and microglia, resulting in allodynia in mice model, which is regulated by spinal Wnt5a (Yuan et al., 2018).
PIs are another cause of neuropathic pain. In HIV seropositive patients, indinavir, saquinavir, and ritonavir are associated with neuropathic pain, and indinavir shows selective cytotoxicity to macrophages in DRG, inducing neuronal atrophy and neurite retraction (Pettersen et al., 2006). Adult rats treated with indinavir develop hind paw mechanical hypersensitivity independent of HIV infection. Treatment with PI activates microglia in the lumbar spinal dorsal horn by inducing the phosphorylation of p38 in microglia, which mimics the clinical features of PI-treated HIV patients (Huang et al., 2017).

\section{Future Perspective}

The prevalence of neuropathic pain varies widely among HIV populations. Take those influence factors described in the chronic pain research into consideration, including gender, race, PI or neurotoxic NRTI drugs usage and cART regimens, high stand of screening criteria and methods should be established to obtain a more accurate epidemiology data. As most works are done by intrathecal injection of gp120 in rat 


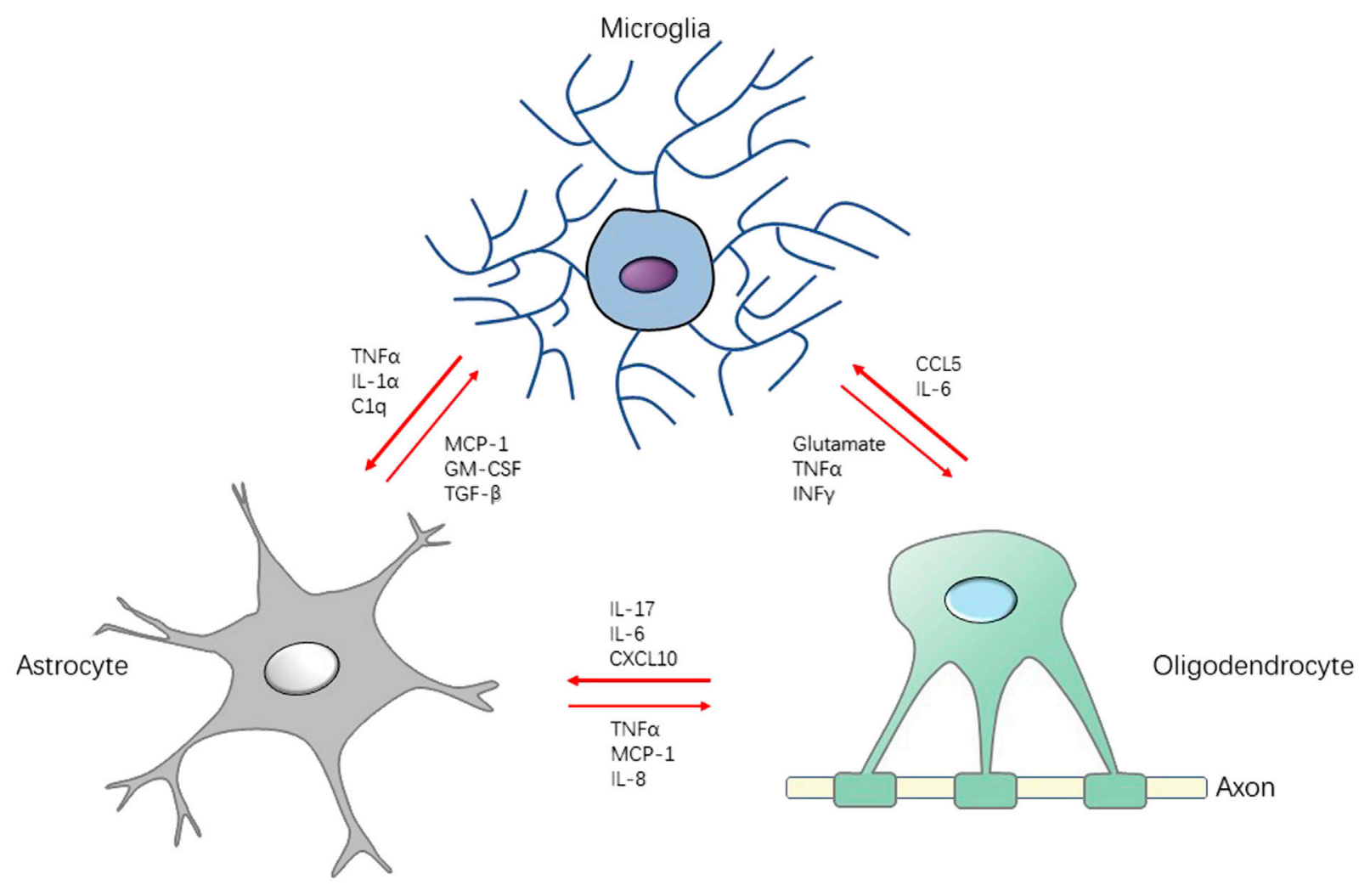

FIGURE 2 | Schematic diagram for the interaction between microglia, astrocytes and oligodendrocytes in neuroinflammation. Stimulated by pathogen or injury, the production of cytokines, chemokines, and growth factors by microglia may induce activation on astrocytes and oligodendrocyte, which accelerates the neuroinflammation in CNS, leading to central sensitization. Conversely, there are some factors (e.g., TGF- $\beta$, IL-10) that attenuate the development of neuroinflammation, serving the function of neuroprotection. TGF- $\beta$ : transforming growth factor- $\beta$; INF $\gamma$ : interferon $\gamma$.

model to simulate the neuropathic pain state in PLWH, which is an exogenous stimulus originated from HIV envelope proteins, whether this method could actually present the neuroinflammation occurs in pain-positive patients is still remain discussion. Actually, immune cells express inflammation modulatory factors (e.g., IL-10 and IL-27) during different phases of HIV infection (Soare et al., 2019). IL-27 receptor, expressed by macrophage, microglia, and astrocytes of the sensory ganglia and spinal cord, its activation has the function of counteracting neuropathic pain (Fonseca et al., 2019). Therefore, both pro-inflammation and anti-inflammation are processing simultaneously between immune cells. It is interesting to investigate the crosstalk between microglia, astrocytes and oligodendrocytes during HIV infection resulting neuropathic pain, which microglia could play a center role of the neuroinflammation. The cellular tropism of HIV strains applicated in the experiment is neglected in the early work. But the study of Ntogwa et al. raises an important question that the signal pathway activated by $\mathrm{X} 4$ gp120 between Schwann cells and macrophages is not involved in the development of R5 gp120-induced neuropathic pain. The role of macrophage in X4 gp120-induced neuroinflammation is not yet fully understood (Ntogwa et al., 2020). It will be critical to do more researches about the neuroinflammation during HIV infection, and identify important targets to design related medication for blocking the progression of neuropathic pain.

\section{AUTHOR CONTRIBUTIONS}

$\mathrm{HL}$ and YF wrote this review manuscript. QW and ZZ designed and supervised this manuscript.

\section{FUNDING}

This study was supported by the National Natural Science Foundation of China (Grant Nos. NSFC 31970938, 81571070), and the Natural Science Research Program of Jiangsu Province (Grant No. BK20191448), the Qing Lan Project, and the Innovation and Entrepreneurship Training Program for College Students in Jiangsu Province (Grant No. 201810304029Z). 


\section{REFERENCES}

Acharjee, S., Noorbakhsh, F., Stemkowski, P. L., Olechowski, C., Cohen, E. A., Ballanyi, K., et al. (2010). HIV-1 viral protein R causes peripheral nervous system injury associated with in vivo neuropathic pain. FASEB j. 24, 4343-4353. doi:10.1096/fj.10-162313

Acharya, P., Lusvarghi, S., Bewley, C. A., and Kwong, P. D. (2015). Hiv-1 gp120 as a therapeutic target: navigating a moving labyrinth. Expert Opin. Ther. Targets 19, 765-783. doi:10.1517/14728222.2015.1010513

Addis, D. R., DeBerry, J. J., and Aggarwal, S. (2020). Chronic pain in hiv. Mol. Pain 16, 174480692092727. doi:10.1177/1744806920927276

Aouizerat, B. E., Miaskowski, C. A., Gay, C., Portillo, C. J., Coggins, T., Davis, H., et al. (2010). Risk factors and symptoms associated with pain in hiv-infected adults. J. Assoc. Nurses AIDS Care 21, 125-133. doi:10.1016/j.jana.2009. 10.003

Asgedom, S. W., Maru, M., Berihun, B., Gidey, K., Niriayo, Y. L., and Atey, T. M. (2020). Immunologic and clinical failure of antiretroviral therapy in people living with human immunodeficiency virus within two years of treatment. Biomed. Res. Int. 2020, 5474103. doi:10.1155/2020/5474103

Balabanov, R., Strand, K., Goswami, R., McMahon, E., Begolka, W., Miller, S. D., et al. (2007). Interferon- -oligodendrocyte interactions in the regulation of experimental autoimmune encephalomyelitis. J. Neurosci. 27, 2013-2024. doi:10.1523/JNEUROSCI.4689-06.2007

Banks, W. A., Freed, E. O., Wolf, K. M., Robinson, S. M., Franko, M., and Kumar, V. B. (2001). Transport of human immunodeficiency virus type 1 pseudoviruses across the blood-brain barrier: role of envelope proteins and adsorptive endocytosis. J. Virol. 75, 4681-4691. doi:10.1128/JVI.75.10. 4681-4691.2001

Ben, H. L., and Rowitch, D. H. (2017). Functional diversity of astrocytes in neural circuit regulation. Nat. Rev. Neurosci. 18, 31-41. doi:10.1038/nrn. 2016.159

Bezzi, P., Domercq, M., Brambilla, L., Galli, R., Schols, D., De Clercq, E., et al. (2001). CXCR4-activated astrocyte glutamate release via TNFa: amplification by microglia triggers neurotoxicity. Nat. Neurosci. 4 (7), 702-710. doi:10.1038/ 89490

Bhangoo, S. K., Ren, D., Miller, R. J., Chan, D. M., Ripsch, M. S., Weiss, C., et al. (2007). Cxcr4 chemokine receptor signaling mediates pain hypersensitivity in association with antiretroviral toxic neuropathy. Brain Behav. Immun. 21, 581-591. doi:10.1016/j.bbi.2006.12.003

Breitbart, W., McDonald, M. V., Rosenfeld, B., Passik, S. D., Hewitt, D., Thaler, H., et al. (1996). Pain in ambulatory aids patients. I: pain characteristics and medical correlates. Pain 68 (2-3), 315-321. doi:10.1016/s0304-3959(96)03215-0

Brew, B. J., Crowe, S. M., Landay, A., Cysique, L. A., and Guillemin, G. (2009). Neurodegeneration and ageing in the haart era. J. Neuroimmune Pharmacol. 4 (2), 163-174. doi:10.1007/s11481-008-9143-1

Bruce, R. D., Merlin, J., Lum, P. J., Ahmed, E., Alexander, C., Corbett, A. H., et al. (2017). 2017 HIVMA of IDSA clinical practice guideline for the management of chronic pain in patients living with HIV. Clin. Infect. Dis. 65 (10), e1-e37. doi:10.1093/cid/cix636

Cannella, B., and Raine, C. S. (2004). Multiple sclerosis: cytokine receptors on oligodendrocytes predict innate regulation. Ann. Neurol. 55 (1), 46-57. doi:10. 1002/ana.10764

Catani, M. V., Corasaniti, M. T., Navarra, M., Nisticò, G., Finazzi-Agrò, A., and Melino, G. (2000). Gp120 induces cell death in human neuroblastoma cells through the cxcr4 and ccr5 chemokine receptors. J. Neurochem. 74 (6), 2373-2379. doi:10.1046/j.1471-4159.2000.0742373.x

Cervia, L. D., McGowan, J. P., and Weseley, A. J. (2010). Clinical and demographic variables related to pain in hiv-infected individuals treated with effective, combination antiretroviral therapy (cart). Pain Med. 11 (4), 498-503. doi:10. 1111/j.1526-4637.2010.00802.x

Chang, V. T., Hwang, S. S., Feuerman, M., Kasimis, B. S., and Thaler, H. T. (2000). The memorial symptom assessment scale short form (msas-sf). Cancer 89 (5), 1162-1171. doi:10.1002/1097-0142(20000901)89:5<1162::aid-cncr26>3.0.co; $2-\mathrm{y}$

Chen, L., Liu, J., Xu, C., Keblesh, J., Zang, W., and Xiong, H. (2011). Hiv-1gp120 induces neuronal apoptosis through enhancement of 4 -aminopyridine-senstive outward k+ currents. Plos One 6, e25994. doi:10.1371/journal.pone.0025994
Chen, Y., Zhang, X., Wang, C., Li, G., Gu, Y., and Huang, L.-Y. M. (2008). Activation of $\mathrm{p} 2 \times 7$ receptors in glial satellite cells reduces pain through downregulation of $\mathrm{p} 2 \times 3$ receptors in nociceptive neurons. Proc. Natl. Acad. Sci. 105, 16773-16778. doi:10.1073/pnas.0801793105

Chi, X., Amet, T., Byrd, D., Chang, K.-H., Shah, K., Hu, N., et al. (2011). Direct effects of hiv-1 tat on excitability and survival of primary dorsal root ganglion neurons: possible contribution to hiv-1-associated pain. Plos One 6, e24412. doi:10.1371/journal.pone.0024412

Cleeland, C. S., and Ryan, K. M. (1994). Pain assessment: global use of the brief pain inventory. Ann. Acad. Med. Singap 23, 129-138.

Costa, F. A. L., and Neto, F. L. M. (2015). Satellite glial cells in sensory ganglia: its role in pain. Braz. J. Anesthesiology (English Edition) 65, 73-81. doi:10.1016/j. bjan.2013.07.01310.1016/j.bjane.2013.07.013

Datta, G., Miller, N. M., Afghah, Z., Geiger, J. D., and Chen, X. (2019). Hiv-1 gp120 promotes lysosomal exocytosis in human schwann cells. Front. Cel. Neurosci. 13, 329. doi:10.3389/fncel.2019.00329

El-Hage, N., Rodriguez, M., Dever, S. M., Masvekar, R. R., Gewirtz, D. A., and Shacka, J. J. (2015). Hiv-1 and morphine regulation of autophagy in microglia: limited interactions in the context of hiv-1 infection and opioid abuse. J. Virol. 89, 1024-1035. doi:10.1128/JVI.02022-14

Ellis, A., and Bennett, D. L. H. (2013). Neuroinflammation and the generation of neuropathic pain. Br. J. Anaesth. 111 (1), 26-37. doi:10.1093/bja/aet128

Ellis, R. J., Rosario, D., Clifford, D. B., McArthur, J. C., Simpson, D., Alexander, T., et al. (2010). Continued high prevalence and adverse clinical impact of human immunodeficiency virus-associated sensory neuropathy in the era of combination antiretroviral therapy: the charter study. Arch. Neurol. 67 (5), 552-558. doi:10.1001/archneurol.2010.76

Eron, J. J., Ashby, M. A., Giordano, M. F., Chernow, M., Reiter, W. M., Deeks, S. G., et al. (1996). Randomised trial of mnrgp120 hiv-1 vaccine in symptomless hiv-1 infection. Lancet 348, 1547-1551. doi:10.1016/s0140-6736(96)05283-x

Fonseca, M. M., Davoli-Ferreira, M., Santa-Cecília, F., Guimarães, R. M., Oliveira, F. F. B., Kusuda, R., et al. (2019). Il-27 counteracts neuropathic pain development through induction of il-10. Front. Immunol. 10, 3059. doi:10. 3389/fimmu.2019.03059

Gao, Y.-J., and Ji, R.-R. (2010). Chemokines, neuronal-glial interactions, and central processing of neuropathic pain. Pharmacol. Ther. 126, 56-68. doi:10. 1016/j.pharmthera.2010.01.002

Gao, Y.-J., Zhang, L., and Ji, R.-R. (2010). Spinal injection of TNF- $\alpha$-activated astrocytes produces persistent pain symptom mechanical allodynia by releasing monocyte chemoattractant protein-1. Glia 58, 1871-1880. doi:10.1002/glia. 21056

Gibson, E. M., Nagaraja, S., Ocampo, A., Tam, L. T., Wood, L. S., Pallegar, P. N., et al. (2019). Methotrexate chemotherapy induces persistent tri-glial dysregulation that underlies chemotherapy-related cognitive impairment. Cell 176, 43-55. doi:10.1016/j.cell.2018.10.049

Gierthmühlen, J., and Baron, R. (2016). Neuropathic pain. Semin. Neurol. 36 462-468. doi:10.1055/s-0036-1584950

Gorry, P., Ong, C., Thorpe, J., Bannwarth, S., Thompson, K., Gatignol, A., et al. (2003). Astrocyte infection by hiv-1: mechanisms of restricted virus replication, and role in the pathogenesis of hiv-1-associated dementia. Chr 1, 463-473. doi:10.2174/1570162033485122

Hanani, M. (2005). Satellite glial cells in sensory ganglia: from form to function. Brain Res. Rev. 48, 457-476. doi:10.1016/j.brainresrev.2004.09.001

Hansen, K. B., Yi, F., Perszyk, R. E., Furukawa, H., Wollmuth, L. P., Gibb, A. J., et al. (2018). Structure, function, and allosteric modulation of nmda receptors. J. Gen. Physiol. 150, 1081-1105. doi:10.1085/jgp.201812032

Hao, S. (2013). The molecular and pharmacological mechanisms of hiv-related neuropathic pain. Cn 11, 499-512. doi:10.2174/1570159X11311050005

Harding, R., Lampe, F. C., Norwood, S., Date, H. L., Clucas, C., Fisher, M., et al. (2010). Symptoms are highly prevalent among hiv outpatients and associated with poor adherence and unprotected sexual intercourse. Sex. Transm. Infections 86, 520-524. doi:10.1136/sti.2009.038505

Herzberg, U., and Sagen, J. (2001). Peripheral nerve exposure to hiv viral envelope protein gp120 induces neuropathic pain and spinal gliosis. J. Neuroimmunol. 116, 29-39. doi:10.1016/s0165-5728(01)00288-0

Hickman, S. E., Kingery, N. D., Ohsumi, T. K., Borowsky, M. L., Wang, L.-c., Means, T. K., et al. (2013). The microglial sensome revealed by direct rna sequencing. Nat. Neurosci. 16, 1896-1905. doi:10.1038/nn.3554 
Holguin, A., O'Connor, K. A., Biedenkapp, J., Campisi, J., Wieseler-Frank, J., Milligan, E. D., et al. (2004). Hiv-1 gp120 stimulates proinflammatory cytokinemediated pain facilitation via activation of nitric oxide synthase-i (nnos). Pain 110, 517-530. doi:10.1016/j.pain.2004.02.018

Hong, S., and Banks, W. A. (2015). Role of the immune system in hiv-associated neuroinflammation and neurocognitive implications. Brain Behav. Immun. 45, 1-12. doi:10.1016/j.bbi.2014.10.008

Hong, S., Dissing-Olesen, L., and Stevens, B. (2016). New insights on the role of microglia in synaptic pruning in health and disease. Curr. Opin. Neurobiol. 36, 128-134. doi:10.1016/j.conb.2015.12.004

Hosokawa, M., Klegeris, A., Maguire, J., and McGeer, P. L. (2003). Expression of complement messenger rnas and proteins by human oligodendroglial cells. Glia 42, 417-423. doi:10.1002/glia.10234

Huang, J., Bloe, C. B., Zhou, X., Wu, S., and Zhang, W. (2020). The role of the spinal wnt signaling pathway in hiv-related neuropathic pain. Cell Mol Neurobiol 40, 1075-1085. doi:10.1007/s10571-020-00805-6

Huang, L.-Y. M., Gu, Y., and Chen, Y. (2013). Communication between neuronal somata and satellite glial cells in sensory ganglia. Glia 61, 1571-1581. doi:10. 1002/glia.22541

Huang, W., Calvo, M., Pheby, T., Bennett, D. L. H., and Rice, A. S. C. (2017). A rodent model of hiv protease inhibitor indinavir induced peripheral neuropathy. Pain 158, 75-85. doi:10.1097/j.pain.0000000000000727

Inoue, K., and Tsuda, M. (2018). Microglia in neuropathic pain: cellular and molecular mechanisms and therapeutic potential. Nat. Rev. Neurosci. 19, 138-152. doi:10.1038/nrn.2018.2

Iwasa, T., Afroz, S., Inoue, M., Arakaki, R., Oshima, M., Raju, R., et al. (2019). Il-10 and cxcl2 in trigeminal ganglia in neuropathic pain. Neurosci. Lett. 703, 132-138. doi:10.1016/j.neulet.2019.03.031

Jensen, M. P., Gammaitoni, A. R., Olaleye, D. O., Oleka, N., Nalamachu, S. R., and Galer, B. S. (2006). The pain quality assessment scale: assessment of pain quality in carpal tunnel syndrome. The J. Pain 7, 823-832. doi:10.1016/j.jpain.2006. 04.003

Ji, R.-R., Berta, T., and Nedergaard, M. (2013). Glia and pain: is chronic pain a gliopathy? Pain 154 (Suppl. 1), S10-S28. doi:10.1016/j.pain.2013.06.022

Ji, R.-R., Chamessian, A., and Zhang, Y.-Q. (2016). Pain regulation by nonneuronal cells and inflammation. Science 354, 572-577. doi:10.1126/science. aaf8924

Ji, R.-R., Kohno, T., Moore, K. A., and Woolf, C. J. (2003). Central sensitization and ltp: do pain and memory share similar mechanisms? Trends Neurosci. 26, 696-705. doi:10.1016/j.tins.2003.09.017

Ji, R.-R., Nackley, A., Huh, Y., Terrando, N., and Maixner, W. (2018). Neuroinflammation and central sensitization in chronic and widespread pain. Anesthesiology 129 (2), 343-366. doi:10.1097/ALN.0000000000002130

Jiao, J. M., So, E., Jebakumar, J., George, M. C., Simpson, D. M., and RobinsonPapp, J. (2016). Chronic pain disorders in HIV primary care: clinical characteristics and association with healthcare utilization. Pain 157 (4), 931-937. doi:10.1097/j.pain.0000000000000462

Kawasaki, Y., Xu, Z.-Z., Wang, X., Park, J. Y., Zhuang, Z.-Y., Tan, P.-H., et al. (2008). Distinct roles of matrix metalloproteases in the early- and late-phase development of neuropathic pain. Nat. Med. 14, 331-336. doi:10.1038/ nm1723

Keswani, S. C., Polley, M., Pardo, C. A., Griffin, J. W., McArthur, J. C., and Hoke, A. (2003). Schwann cell chemokine receptors mediate hiv-1 gp120 toxicity to sensory neurons. Ann. Neurol. 54, 287-296. doi:10.1002/ana.10645

Kiguchi, N., Kobayashi, D., Saika, F., Matsuzaki, S., and Kishioka, S. (2017). Pharmacological regulation of neuropathic pain driven by inflammatory macrophages. Ijms 18 (11), 2296. doi:10.3390/ijms18112296

Kim, S., Maynard, J. C., Strickland, A., Burlingame, A. L., and Milbrandt, J. (2018). Schwann cell o-glcnacylation promotes peripheral nerve remyelination via attenuation of the ap-1 transcription factor jun. Proc. Natl. Acad. Sci. USA 115, 8019-8024. doi:10.1073/pnas.1805538115

Kobayashi, K., Takahashi, E., Miyagawa, Y., Yamanaka, H., and Noguchi, K. (2011). Induction of the $\mathrm{p} 2 \times 7$ receptor in spinal microglia in a neuropathic pain model. Neurosci. Lett. 504 (1), 57-61. doi:10.1016/j.neulet.2011.08.058

Krebs, E. E., Lorenz, K. A., Bair, M. J., Damush, T. M., Wu, J., Sutherland, J. M., et al. (2009). Development and initial validation of the peg, a three-item scale assessing pain intensity and interference. J. Gen. Intern. Med. 24, 733-738. doi:10.1007/s11606-009-0981-1
Lawson, E., Sabin, C., Perry, N., Richardson, D., Gilleece, Y., Churchill, D., et al. (2015). Is hiv painful? An epidemiologic study of the prevalence and risk factors for pain in hiv-infected patients. Clin. J. Pain 31, 813-819. doi:10.1097/AJP. 0000000000000162

Lee, K. A., Gay, C., Portillo, C. J., Coggins, T., Davis, H., Pullinger, C. R., et al. (2009). Symptom experience in hiv-infected adults: a function of demographic and clinical characteristics. J. Pain Symptom Manage. 38, 882-893. doi:10.1016/ j.jpainsymman.2009.05.013

Lee, S., Shi, X. Q., Fan, A., West, B., and Zhang, J. (2018). Targeting macrophage and microglia activation with colony stimulating factor 1 receptor inhibitor is an effective strategy to treat injury-triggered neuropathic pain. Mol. Pain 14, 174480691876497. doi:10.1177/1744806918764979

Li, B., Shi, Y., Shu, J., Gao, J., Wu, P., and Tang, S.-J. (2013). Wingless-type mammary tumor virus integration site family, member $5 \mathrm{a}$ (wnt5a) regulates human immunodeficiency virus type 1 (hiv-1) envelope glycoprotein 120 (gp120)-induced expression of pro-inflammatory cytokines via the ca2+/ calmodulin-dependent protein kinase ii (camkii) and c-jun n-terminal kinase (jnk) signaling pathways. J. Biol. Chem. 288, 13610-13619. doi:10. 1074/jbc.M112.381046

Linnerbauer, M., Wheeler, M. A., and Quintana, F. J. (2020). Astrocyte crosstalk in cns inflammation. Neuron 108, 608-622. doi:10.1016/j. neuron.2020.08.012

Liu, B., Liu, X., and Tang, S.-J. (2016). Interactions of opioids and hiv infection in the pathogenesis of chronic pain. Front. Microbiol. 7, 103. doi:10.3389/fmicb. 2016.00103

Liu, Z. Y., Song, Z. W., Guo, S. W., He, J. S., Wang, S. Y., Zhu, J. G., et al. (2019). Cxcl12/cxcr4 signaling contributes to neuropathic pain via central sensitization mechanisms in a rat spinal nerve ligation model. Cns Neurosci. Ther. 25, 922-936. doi:10.1111/cns.13128

Loeser, J. D., and Treede, R.-D. (2008). The kyoto protocol of IASP basic pain terminology 论. Pain 137, 473-477. doi:10.1016/j.pain.2008.04.025

Lotankar, S., Prabhavalkar, K. S., and Bhatt, L. K. (2017). Biomarkers for Parkinson's disease: recent advancement. Neurosci. Bull. 33, 585-597. doi:10. 1007/s12264-017-0183-5

Loubiere, S., Meiners, C., Sloan, C., Freedberg, K. A., and Yazdanpanah, Y. (2010). Economic evaluation of art in resource-limited countries. Curr. Opin. HIV AIDS 5, 225-231. doi:10.1097/COH.0b013e3283384a9d

Madden, V. J., Parker, R., and Goodin, B. R. (2020). Chronic pain in people with hiv: a common comorbidity and threat to quality of life. Pain Manag. 10, 253-260. doi:10.2217/pmt-2020-0004

Mameli, G., Deshmane, S. L., Ghafouri, M., Cui, J., Simbiri, K., Khalili, K., et al. (2007). $\mathrm{C} / \mathrm{EBP} \beta$ regulates human immunodeficiency virus 1 gene expression through its association with cdk9. J. Gen. Virol. 88, 631-640. doi:10.1099/vir.0.82487-0

Manji, H. (2000). Neuropathy in hiv infection. Curr. Opin. Neurol. 13, 589-592. doi:10.1097/00019052-200010000-00014

Marchionni, I., Beaumont, M., and Maccaferri, G. (2012). The chemokine cxcl12 and the hiv-1 envelope protein gp120 regulate spontaneous activity of cajalretzius cells in opposite directions. J. Physiol. 590, 3185-3202. doi:10.1113/ jphysiol.2011.224873

Mawuntu, A. H. P., Mahama, C. N., Khosama, H., Estiasari, R., and Imran, D. (2018). Early detection of peripheral neuropathy using stimulated skin wrinkling test in human immunodeficiency virus infected patients. Medicine (Baltimore) 97, el1526. doi:10.1097/MD.0000000000011526

Mayo, L., Trauger, S. A., Blain, M., Nadeau, M., Patel, B., Alvarez, J. I., et al. (2014). Regulation of astrocyte activation by glycolipids drives chronic cns inflammation. Nat. Med. 20, 1147-1156. doi:10.1038/nm.3681

Melli, G., Keswani, S. C., Fischer, A., Chen, W., and Höke, A. (2006). Spatially distinct and functionally independent mechanisms of axonal degeneration in a model of hiv-associated sensory neuropathy. Brain 129, 1330-1338. doi:10. 1093/brain/awl058

Menezes, C. N., Maskew, M., Sanne, I., Crowther, N. J., and Raal, F. J. (2011). A longitudinal study of stavudine-associated toxicities in a large cohort of south african hiv infected subjects. Bmc Infect. Dis. 11, 244. doi:10.1186/1471-2334$11-244$

Merlin, J. S., Long, D., Becker, W. C., Cachay, E. R., Christopoulos, K. A., Claborn, K., et al. (2018). Brief report: the association of chronic pain and long-term opioid therapy with hiv treatment outcomes. J. Acquir Immune Defic Syndr. 79, 77-82. doi:10.1097/QAI.0000000000001741 
Merlin, J. S., Walcott, M. M., Herbey, I., Chamot, E., Ritchie, C., Saag, M. S., et al. (2014). Qualitative investigation of a brief chronic pain screening tool in hivinfected patients. AIDS Patient Care and STDs 28, 176-182. doi:10.1089/apc. 2014.0006

Merlin, J. S., Westfall, A. O., Chamot, E., Overton, E. T., Willig, J. H., Ritchie, C., et al. (2013). Pain is independently associated with impaired physical function in hiv-infected patients. Pain Med. 14, 1985-1993. doi:10.1111/pme.12255

Merlin, J. S., Westfall, A. O., Raper, J. L., Zinski, A., Norton, W. E., Willig, J. H., et al. (2012). Pain, mood, and substance abuse in HIV: implications for clinic visit utilization, antiretroviral therapy adherence, and virologic failure. J. Acquir Immune Defic Syndr. 61, 164-170. doi:10.1097/QAI.0b013e3182662215

Miaskowski, C., Penko, J. M., Guzman, D., Mattson, J. E., Bangsberg, D. R., and Kushel, M. B. (2011). Occurrence and characteristics of chronic pain in a community-based cohort of indigent adults living with hiv infection. J. Pain 12, 1004-1016. doi:10.1016/j.jpain.2011.04.002

Milligan, E. D., Mehmert, K. K., Hinde, J. L., Harvey, L. O., Martin, D., Tracey, K. J., et al. (2000). Thermal hyperalgesia and mechanical allodynia produced by intrathecal administration of the human immunodeficiency virus-1 (hiv-1) envelope glycoprotein, gp120. Brain Res. 861, 105-116. doi:10.1016/s00068993(00)02050-3

Milligan, E. D., O'Connor, K. A., Nguyen, K. T., Armstrong, C. B., Twining, C., Gaykema, R. P. A., et al. (2001a). Intrathecal hiv-1 envelope glycoprotein gp120 induces enhanced pain states mediated by spinal cord proinflammatory cytokines. J. Neurosci. 21, 2808-2819. doi:10.1523/ jneurosci.21-08-02808.2001

Milligan, E. D., O'Connor, K. A., Nguyen, K. T., Armstrong, C. B., Twining, C., Gaykema, R. P. A., et al. (2001b). Intrathecal hiv-1 envelope glycoprotein gp120 induces enhanced pain states mediated by spinal cord proinflammatory cytokines. J. Neurosci. 21, 2808-2819. doi:10.1523/jneurosci.21-08-02808.2001

Monif, M., Reid, C. A., Powell, K. L., Drummond, K. J., O’Brien, T. J., and Williams, D. A. (2016). Interleukin-1 $\beta$ has trophic effects in microglia and its release is mediated by P2X7R pore. J. Neuroinflammation 13, 173. doi:10.1186/s12974016-0621-8

Moyon, S., Dubessy, A. L., Aigrot, M. S., Trotter, M., Huang, J. K., Dauphinot, L., et al. (2015). Demyelination causes adult cns progenitors to revert to an immature state and express immune cues that support their migration. J. Neurosci. 35, 4-20. doi:10.1523/JNEUROSCI.0849-14.2015

Nair, S., Mary, T., Prarthana, S., and Harrison, P. (2009). Prevalence of pain in patients with hiv/aids: a cross-sectional survey in a south indian state. Indian J. Palliat. Care 15, 67-70. doi:10.4103/0973-1075.53550

Nave, K.-A., and Trapp, B. D. (2008). Axon-glial signaling and the glial support of axon function. Annu. Rev. Neurosci. 31, 535-561. doi:10.1146/annurev.neuro. 30.051606.094309

Navis, A., Jiao, J., George, M. C., Simpson, D., and Robinson-Papp, J. (2018). Comorbid pain syndromes in hiv-associated peripheral neuropathy. Pain Med. 19, 1445-1450. doi:10.1093/pm/pnx129

Newshan, G., Bennett, J., and Holman, S. (2002). Pain and other symptoms in ambulatory hiv patients in the age of highly active antiretroviral therapy. J. Assoc. Nurses AIDS Care 13, 78-83. doi:10.1016/S10553290(06)60373-7

Ntogwa, M., Imai, S., Hiraiwa, R., Koyanagi, M., Matsumoto, M., Ogihara, T., et al. (2020). Schwann cell-derived cxcll contributes to human immunodeficiency virus type 1 gp120-induced neuropathic pain by modulating macrophage infiltration in mice. Brain Behav. Immun. 88, 325-339. doi:10.1016/j.bbi. 2020.03.027

Oh, S. B., Tran, P. B., Gillard, S. E., Hurley, R. W., Hammond, D. L., and Miller, R. J. (2001). Chemokines and glycoprotein 120 produce pain hypersensitivity by directly exciting primary nociceptive neurons. J. Neurosci. 21, 5027-5035. doi:10.1523/jneurosci.21-14-05027.2001

Paolicelli, R. C., Bolasco, G., Pagani, F., Maggi, L., Scianni, M., Panzanelli, P., et al. (2011). Synaptic pruning by microglia is necessary for normal brain development. Science 333, 1456-1458. doi:10.1126/science.1202529

Parker, R., Stein, D. J., and Jelsma, J. (2014). Pain in people living with hiv/aids: a systematic review. J. Int. AIDS Soc. 17 (1), 18719. doi:10.7448/IAS.17.1.18719

Patrizio, M., and Levi, G. (1994). Glutamate production by cultured microglia: differences between rat and mouse, enhancement by lipopolysaccharide and lack effect of hiv coat protein gp120 and depolarizing agents. Neurosci. Lett. 178 (2), 184-188. doi:10.1016/0304-3940(94)90755-2
Pettersen, J. A., Jones, G., Worthington, C., Krentz, H. B., Keppler, O. T., Hoke, A., et al. (2006). Sensory neuropathy in human immunodeficiency virus/acquired immunodeficiency syndrome patients: protease inhibitorâ $€$ "mediated neurotoxicity. Ann. Neurol. 59 (5), 816-824. doi:10.1002/ana.20816

Phillips, T. J. C., Brown, M., Ramirez, J. D., Perkins, J., Woldeamanuel, Y. W., Williams, A. C. d. C., et al. (2014). Sensory, psychological, and metabolic dysfunction in hiv-associated peripheral neuropathy: a cross-sectional deep profiling study. Pain 155, 1846-1860. doi:10.1016/j.pain.2014.06.014

Porcheray, F., Léone, C., Samah, B., Rimaniol, A.-C., Dereuddre-Bosquet, N., and Gras, G. (2006). Glutamate metabolism in hiv-infected macrophages: implications for the cns. Am. J. Physiology-Cell Physiol. 291, C618-C626. doi:10.1152/ajpcell.00021.2006

Qin, C., Zhou, L.-Q., Ma, X.-T., Hu, Z.-W., Yang, S., Chen, M., et al. (2019). Dual functions of microglia in ischemic stroke. Neurosci. Bull. 35, 921-933. doi:10. 1007/s12264-019-00388-3

Ramesh, G., Benge, S., Pahar, B., and Philipp, M. T. (2012). A possible role for inflammation in mediating apoptosis of oligodendrocytes as induced by the lyme disease spirochete borrelia burgdorferi. J. Neuroinflammation 9, 72 . doi:10.1186/1742-2094-9-72

Ramesh, G., MacLean, A. G., and Philipp, M. T. (2013). Cytokines and chemokines at the crossroads of neuroinflammation, neurodegeneration, and neuropathic pain. Mediators Inflamm. 2013, 1. doi:10.1155/2013/480739

Robinson-Papp, J., Gonzalez-Duarte, A., Simpson, D. M., Rivera-Mindt, M., and Morgello, S. (2009). The roles of ethnicity and antiretrovirals in hiv-associated polyneuropathy: a pilot study. J. Acquir Immune Defic Syndr. 51, 569-573. doi:10.1097/QAI.0b013e3181adcefa

Rothhammer, V., and Quintana, F. J. (2015). Control of autoimmune cns inflammation by astrocytes. Semin. Immunopathol 37, 625-638. doi:10.1007/ s00281-015-0515-3

Ru, W., Liu, X., Bae, C., Shi, Y., Walikonis, R., Mo Chung, J., et al. (2019). Microglia mediate hiv-1 gp120-induced synaptic degeneration in spinal pain neural circuits. J. Neurosci. 39, 8408-8421. doi:10.1523/JNEUROSCI.2851-18.2019

Sanchis, P., Fernández-Gayol, O., Comes, G., Escrig, A., Giralt, M., Palmiter, R. D., et al. (2020). Interleukin-6 derived from the central nervous system may influence the pathogenesis of experimental autoimmune encephalomyelitis in a cell-dependent manner. Cells 9, 330. doi:10.3390/cells9020330

Sanna, M. D., Ghelardini, C., and Galeotti, N. (2016). Blockade of the spinal bdnfactivated jnk pathway prevents the development of antiretroviral-induced neuropathic pain. Neuropharmacology 105, 543-552. doi:10.1016/j. neuropharm.2016.02.016

Sasaki, Y., Hackett, A. R., Kim, S., Strickland, A., and Milbrandt, J. (2018). Dysregulation of NAD+ metabolism induces a schwann cell dedifferentiation program. J. Neurosci. 38, 6546-6562. doi:10.1523/ JNEUROSCI.3304-17.2018

Schoeniger-Skinner, D. K., Ledeboer, A., Frank, M. G., Milligan, E. D., Poole, S., Martin, D., et al. (2007). Interleukin-6 mediates low-threshold mechanical allodynia induced by intrathecal hiv-1 envelope glycoprotein gp120. Brain Behav. Immun. 21, 660-667. doi:10.1016/j.bbi.2006.10.010

Scholz, J., Finnerup, N. B., Attal, N., Aziz, Q., Baron, R., Bennett, M. I., et al. (2019). The iasp classification of chronic pain for icd-11: chronic neuropathic pain. Pain 160, 53-59. doi:10.1097/j.pain.0000000000001365

Shah, A., Singh, D. P., Buch, S., and Kumar, A. (2011a). HIV-1 envelope protein gp120 up regulates CCL5 production in astrocytes which can be circumvented by inhibitors of NF-kB pathway. Biochem. Biophysical Res. Commun. 414, 112-117. doi:10.1016/j.bbrc.2011.09.033

Shah, A., Verma, A. S., Patel, K. H., Noel, R., Rivera-Amill, V., Silverstein, P. S., et al. (2011b). Hiv-1 gp120 induces expression of il-6 through a nuclear factorkappa b-dependent mechanism: suppression by gp120 specific small interfering rna. Plos One 6, e21261. doi:10.1371/journal.pone.0021261

Shi, Y., Shu, J., Liang, Z., Yuan, S., and Tang, S.-J. (2016). Oligodendrocytes in HIVassociated pain pathogenesis. Mol. Pain 12, 174480691665684. doi:10.1177/ 1744806916656845

Silva, R. L., Lopes, A. H., Guimarães, R. M., and Cunha, T. M. (2017). Cxcl1/cxcr2 signaling in pathological pain: role in peripheral and central sensitization. Neurobiol. Dis. 105, 109-116. doi:10.1016/j.nbd.2017.06.001

Silverberg, M. J., Jacobson, L. P., French, A. L., Witt, M. D., and Gange, S. J. (2009). Age and racial/ethnic differences in the prevalence of reported symptoms in human immunodeficiency virus-infected persons on 
antiretroviral therapy. J. Pain Symptom Manage. 38, 197-207. doi:10.1016/ j.jpainsymman.2008.08.007

Simpson, D. M., Kitch, D., Evans, S. R., McArthur, J. C., Asmuth, D. M., Cohen, B., et al. (2006). Hiv neuropathy natural history cohort study: assessment measures and risk factors. Neurology 66, 1679-1687. doi:10.1212/01.wnl.0000218303.48113.5d

Soare, A. Y., Durham, N. D., Gopal, R., Tweel, B., Hoffman, K. W., Brown, J. A., et al. (2018). P2X antagonists inhibit HIV-1 productive infection and inflammatory cytokines interleukin-10 (IL-10) and IL-1 $\beta$ in a human tonsil explant model. J. Virol. 93, e01186-18. doi:10.1128/JVI.01186-18

Sommer, C., Leinders, M., and Üçeyler, N. (2018). Inflammation in the pathophysiology of neuropathic pain. Pain 159, 595-602. doi:10.1097/j.pain. 0000000000001122

Sorkin, L. S., and Doom, C. M. (2000). Epineurial application of TNF elicits an acute mechanical hyperalgesia in the awake rat. J. Peripher. Nerv Syst. 5, 96-100. doi:10.1046/j.1529-8027.2000.00012.x

Tagliati, M., Grinnell, J., Godbold, J., and Simpson, D. M. (1999). Peripheral nerve function in HIV infection: clinical, electrophysiologic, and laboratory findings. Arch. Neurol. 56, 84-89. doi:10.1001/archneur.56.1.84

Tian, C., Sun, L., Jia, B., Ma, K., Curthoys, N., Ding, J., et al. (2012). Mitochondrial glutaminase release contributes to glutamate-mediated neurotoxicity during human immunodeficiency virus-1 infection. J. Neuroimmune Pharmacol. 7, 619-628. doi:10.1007/s11481-012-9364-1

Togashi, H., Sasaki, M., Frohman, E., Taira, E., Ratan, R. R., Dawson, T. M., et al. (1997). Neuronal (type I) nitric oxide synthase regulates nuclear factor B activity and immunologic (type II) nitric oxide synthase expression. Proc. Natl. Acad. Sci. 94 (6), 2676-2680. doi:10.1073/pnas.94.6.2676

Treede, R. D., Rief, W., Barke, A., Aziz, Q., Bennett, M. I., Benoliel, R., et al. (2019). Chronic pain as a symptom or a disease: the iasp classification of chronic pain for the international classification of diseases (icd-11). Pain 160, 19-27. doi:10. 1097/j.pain.0000000000001384

Tsao, J. C. I., Stein, J. A., and Dobalian, A. (2010). Sex differences in pain and misuse of prescription analgesics among persons with hiv. Pain Med. 11, 815-824. doi:10.1111/j.1526-4637.2010.00858.x

Tsuda, M. (2018). Modulation of pain and itch by spinal glia. Neurosci. Bull. 34, 178-185. doi:10.1007/s12264-017-0129-y

Tzartos, J. S., Friese, M. A., Craner, M. J., Palace, J., Newcombe, J., Esiri, M. M., et al. (2008). Interleukin-17 production in central nervous system-infiltrating $t$ cells and glial cells is associated with active disease in multiple sclerosis. Am. J. Pathol. 172, 146-155. doi:10.2353/ajpath.2008.070690

Urwin, M., Symmons, D., Allison, T., Brammah, T., Busby, H., Roxby, M., et al. (1998). Estimating the burden of musculoskeletal disorders in the community: the comparative prevalence of symptoms at different anatomical sites, and the relation to social deprivation. Ann. Rheum. Dis. 57, 649-655. doi:10.1136/ard.57.11.649

Wagner, R., and Myers, R. R. (1996). Endoneurial injection of TNF- $\alpha$ produces neuropathic pain behaviors. Neuroreport 7, 2897-2902. doi:10.1097/00001756199611250-00018

Wallace, V. C. J., Blackbeard, J., Segerdahl, A. R., Hasnie, F., Pheby, T., McMahon, S. B., et al. (2007). Characterization of rodent models of hiv-gp120 and antiretroviral-associated neuropathic pain. Brain 130, 2688-2702. doi:10.1093/ brain/awm195

Wang, X., Zhao, Y., Zhang, X., Badie, H., Zhou, Y., Mu, Y., et al. (2013). Loss of sorting nexin 27 contributes to excitatory synaptic dysfunction by modulating glutamate receptor recycling in down's syndrome. Nat. Med. 19, 473-480. doi:10.1038/nm.3117

Wang, Y., Liao, J., Tang, S.-J., Shu, J., and Zhang, W. (2017). HIV-1 gp120 upregulates brain-derived neurotrophic factor (BDNF) expression in BV2 cells via the wnt/ $\beta$-catenin signaling pathway. J. Mol. Neurosci. 62 (2), 199-208. doi:10.1007/s12031-017-0931-z
Wu, S., Yang, S., Bloe, C. B., Zhuang, R., Huang, J., and Zhang, W. (2021). Identification of key genes and pathways in mouse spinal cord involved in ddcinduced neuropathic pain by transcriptome sequencing. J. Mol. Neurosci. 71, 651-661. doi:10.1007/s12031-020-01686-6

Wu, T., Zhang, J., Geng, M., Tang, S.-J., Zhang, W., and Shu, J. (2017). Nucleoside reverse transcriptase inhibitors (nrtis) induce proinflammatory cytokines in the cns via wnt5a signaling. Sci. Rep. 7 (1), 4117. doi:10.1038/s41598-017-03446-w

Xin, W.-J. (2019). On the role of microglia in trigeminal neuropathic pain. Neurosci. 414, 297-298. doi:10.1016/j.neuroscience.2019.05.056

Yi, H., Liu, S., Kashiwagi, Y., Ikegami, D., Huang, W., Kanda, H., et al. (2018a). Phosphorylated CCAAT/enhancer binding protein $\beta$ contributes to rat HIVrelated neuropathic pain: in vitro and in vivo studies. J. Neurosci. 38 (3), 555-574. doi:10.1523/JNEUROSCI.3647-16.2017

Yi, Z., Xie, L., Zhou, C., Yuan, H., Ouyang, S., Fang, Z., et al. (2018b). P2Y12 receptor upregulation in satellite glial cells is involved in neuropathic pain induced by HIV glycoprotein 120 and $2^{\prime}, 3^{\prime}$-dideoxycytidine. Purinergic Signal. 14, 47-58. doi:10.1007/s11302-017-9594-z

Yuan, S.-B., Ji, G., Li, B., Andersson, T., Neugebauer, V., and Tang, S.-J. (2015). A wnt5a signaling pathway in the pathogenesis of hiv-1 gp120-induced pain. Pain 156, 1311-1319. doi:10.1097/j.pain.0000000000000177

Yuan, S.-B., Shi, Y., Chen, J., Zhou, X., Li, G., Gelman, B. B., et al. (2014). Gp120 in the pathogenesis of human immunodeficiency virus-associated pain. Ann. Neurol. 75, 837-850. doi:10.1002/ana.24139

Yuan, S., Shi, Y., Guo, K., and Tang, S.-J. (2018). Nucleoside reverse transcriptase inhibitors (nrtis) induce pathological pain through wnt5a-mediated neuroinflammation in aging mice. J. Neuroimmune Pharmacol. 13, 230-236. doi:10.1007/s11481-018-9777-6

Zeis, T., and Schaeren-Wiemers, N. (2008). Lame ducks or fierce creatures? - the role of oligodendrocytes in multiple sclerosis. J. Mol. Neurosci. 35, 91-100. doi:10.1007/s12031-008-9042-1

Zhang, J.-W., Klemm, D. J., Vinson, C., and Lane, M. D. (2004). Role of CREB in transcriptional regulation of CCAAT/Enhancer-binding protein $\beta$ gene during adipogenesis. J. Biol. Chem. 279, 4471-4478. doi:10.1074/jbc. M311327200

Zhao, H., Alam, A., Chen, Q., Eusman, M. A., Pal, A., Eguchi, S., et al. (2017). The role of microglia in the pathobiology of neuropathic pain development: what do we know? Br. J. Anaesth. 118, 504-516. doi:10.1093/bja/aex006

Zhao, S., Zhou, Y., Fan, Y., Gong, Y., Yang, J., Yang, R., et al. (2019). Involvement of purinergic $2 \mathrm{X} 4$ receptor in glycoprotein 120-induced pyroptosis in dorsal root ganglia. J. Neurochem. 151, 584-594. doi:10.1111/jnc.14850

Zheng, W., Ouyang, H., Zheng, X., Liu, S., Mata, M., Fink, D. J., et al. (2011a). Glial TNF $\alpha$ in the spinal cord regulates neuropathic pain induced by HIV gp120 application in rats. Mol. Pain 7, 1744. doi:10.1186/1744-8069-7-40

Zheng, X., Ouyang, H., Liu, S., Mata, M., Fink, D. J., and Hao, S. (2011b). TNFa is involved in neuropathic pain induced by nucleoside reverse transcriptase inhibitor in rats. Brain Behav. Immun. 25, 1668-1676. doi:10.1016/j.bbi. 2011.06.010

Conflict of Interest: The authors declare that the research was conducted in the absence of any commercial or financial relationships that could be construed as a potential conflict of interest.

Copyright $(2021 \mathrm{Lu}, \mathrm{Fu}$, Wei and Zhang. This is an open-access article distributed under the terms of the Creative Commons Attribution License (CC BY). The use, distribution or reproduction in other forums is permitted, provided the original author(s) and the copyright owner(s) are credited and that the original publication in this journal is cited, in accordance with accepted academic practice. No use, distribution or reproduction is permitted which does not comply with these terms. 